\title{
Managerial Competency Models: A Critical Review and Proposed Holistic-Domain Model
}

\author{
Maxwell Asumeng, PhD. \\ Department of Psychology \\ University of Ghana, Legon \\ E-mail: maxysumeng@gmail.com / masumeng@ug.edu.gh
}

Received: May 8, 2014

doi:10.5296/jmr.v6i4.5596
Accepted: June 24, 2014

Published: October 1, 2014

URL: http://dx.doi.org/10.5296/jmr.v6i4.5596

\begin{abstract}
Major generic managerial competency models located in the literature capture business skills, intra-personal skills, interpersonal skills, and leadership skills as important competencies for effective performance. However, while these competencies are necessary for effective managerial performance, the models do not emphasize career and mentoring skills as important managerial competencies, although conceptual and empirical evidence suggest that they are important for managerial effectiveness. This leaves a gap in managerial competency literature, that is lack of comprehensive and holistic model that captures the key competencies. This paper provides evidence on this gap in the literature by reviewing key competency models :behavioural; functional; job competency; holistic; multi-dimensional; and domain model. It provides evidence on the relevance of career and mentoring skills to managerial effectiveness. The paper then proposes holistic-domain model which appears more comprehensive compared to other models located in extant literature as, in addition to business, intra-personal, interpersonal and leadership skills, it integrates career and mentoring skills.
\end{abstract}

Keywords: Managerial competence, Competence model, Management development, First-class manager, Meta-competencies, managerial psychology 


\section{Introduction}

Key generic managerial competency models located in the literature capture business skills, intra-personal skills; interpersonal skills; and leadership skills as important for effective managerial performance. However, while these competencies are necessary for effective managerial performance, the models do not emphasize career and mentoring skills as important managerial competencies. However, a critical review of the managerial competency literature indicates that career and mentoring skills are important for effective managerial performance. This leaves a gap in managerial competency literature; the development of a comprehensive and holistic domain model which captures career and mentoring skills as additional competencies. This paper addresses the gap in the literature by proposing a holistic-domain model of managerial competency with expanded domain as it captures six key domains essential for managerial performance: business, intra-personal, interpersonal, leadership, career and mentoring skills. Firstly, the paper examines the concept and historical development of managerial competence, and highlights the differences between core and generic competences. Secondly, the paper provides evidence on the gap in managerial competency models by reviewing key generic competency models located in the literature in turns: behavioural (Boyatzis, 1982, 2008, 2009; McCleland, 1973, 1998); functional (Knasel \& Meed, 1994; job competency(Mansfield \& Mathews, 1985); holistic (Cheetham \& Chivers, 1996, 1998); multi-dimensional(Le Deist et al., 2005); and the domain model(Hogan \& Warrenfeltz, 2003) highlighting the strengths and weaknesses in each model, and how they all ignore career and mentoring skills. Thirdly, evidence on the relationships between career skills, mentoring skills and managerial effectiveness is provided. Fourthly, drawing on the review, on conceptual and empirical grounds, the paper then proposes an extended holistic-domain model which has enhanced explanatory power compared to other models as it integrates career and mentoring skills with business, intra-personal, interpersonal and leadership skills. It provides taxonomy of the key elements in the model, the behavioural indicators, and the protocol for measuring and assessing the skills. Finally, theoretical, practical and research implications of the model for human resources practitioners, academic and researchers are provided.

\section{The Concept and Historical Development of Managerial Competence}

White (1959) was the first to use the term 'competence' precisely to describe personality characteristics, in particular, scholastic intelligence/cognitive intelligence associated with high motivation and superior performance at work. On the basis of this definition, scores on scholastic intelligence tests were used as predictors of successful performance in organisations although successful performance seldom related to scores on such intelligence tests. McClelland (1973) argued that intelligence tests were not necessarily good predictors of successful performance at work, rather, they predicted academic aptitudes and potentials which may or may not be translated into any particular work situation. Thus, the assessment of competency solely on the basis of intelligence and academic aptitudes and knowledge is limiting because it does not reflect conditions directly relating to work, therefore, does not predict work performance McClelland (1973) argued that the definition of competency should relate to work behaviours and supported the proposition that behaviours were more 
likely to have a stronger and better predictive validity for managerial performance and effectiveness. Building on McClelland's (1973) view, Boyatzis (1982) defined competence as performance capability that distinguish high- form low-performing managers, and empirically identified a list of managerial competencies including personality traits, cognitive skills and interpersonal/social skills. This corroborated McClelland (1973) and supported by later researchers (Hogan \&Warrenfeltz, 2003; Spencer \& Spencer, 1993).

From a human resources perspective, Lado and Wilson (1994) conceptualised managerial competence as the capability of a manager to determine the acquisition, development, and deployment of organisational resources, and the conversion of these resources into valuable products and services to deliver value to organisational stakeholders.

In contemporary organisations, the term 'competence' or 'competency' is conceptualised or defined in relation to performance management systems, where managers are appraised against technical job function requirements, and in relation to precise performance criteria (Cheng \& Bliese, 2002). This is a view of competency mainly predominant in the UK, where the Standards Programme defines competency as: 'a description of something which a person who works in a given occupational area should be able to do; it is a description of an action, behaviour or outcome which a person should be able to demonstrate' (Employment Department, 1991:5). According to this definition, competency comprises the knowledge, skills and behaviours or psycho-social characteristics needed to perform a role effectively in an organisation to enable the organisation to achieve its strategic goals (Le Deist et al., 2005). In sum, competencies predict effectiveness in managerial performance in organisations (Boyatsiz, 2008, 2009)

\section{Generic and Core Competencies}

Competencies are generally developed to suit specific organisational needs as organisations set their own standards of such competencies. Core competencies are specific to the requirements of a particular job in a particular situation whereas generic competencies are overarching and common to all occupations and span across all organisations. Generic competencies are believed to be fundamental to effective performance in all (or most) occupations (Cheetham \& Chivers, 1996). The criteria that may be used to define either generic or core competencies have implication for the indicators that may be used to measure and assess competency. In turn, the set of criteria or indicators that are used to define or determine competency has implication for the competency model one subscribes to. Hence, the different criteria espoused by different academics, researchers and practitioners, and the differing contexts in which competencies are defined and employed in analysis, has led to the development of various models of managerial competencies.

\section{What is a Competence Model?}

A competence model, in a managerial context, describes the performance criteria or the description of the characteristics of a competence performance against which a managers' performance is measured, reviewed and evaluated. It identifies and describes the knowledge, skills and behaviours needed to perform a role effectively in an organisation to achieve the 
organisation's goals. It demonstrates how competent performance is to be recognised in organisations and guides them to define what was done, what is being done and what needs to be done. It is useful for human resources management, specifically, as a guide for personnel selection, performance appraisal, distinguishing high- from low-performing managers, determining managerial effectiveness and professional development (Amage, Rinthasong \& Sonsong, 2014;Boyatsiz, 2008; Cheetham \& Chivers, 1996;Church \&Rotolo, 2013; Le Deist, Delamaire \& Winterton, 2005; Lucia \& Lepsinger, 1999; Naquin \& Holton, 2006).

\section{Generic Competency Models}

Generic competency models are concerned with general competencies required for managerial success whereas, core competencies are concerned with the capabilities required for effective performance in specific organisations (Lucia \& Lepsinger, 1999). It is important to identify the specific competencies relevant to particular organisations in order to determine the performance criteria that can be used to determine effectiveness specific to that organisation. However, since the focus of this paper is not on specific organisations, but on managers in the general working population the review will focus on generic models, starting with behavioural models.

\subsection{Behavioural Models}

The behavioural models of managerial competence (Boyatzis, 1982, 2008; McCleland, 1998), emphasise that job related behaviours are fundamental for effective performance. According to the behaviour models, a number of behaviours that are better predictors of performance capability/ managerial success/outstanding performance are :achievement orientation; analytical thinking; conceptual / inductive thinking; developing others; flexibility; impact and influence; information seeking; initiative; interpersonal understanding; organisational awareness; self confidence; and team leadership.

The behavioural model of competencies can be considered as a valuable approach to the prediction and assessment of managerial performance, compared to the hitherto scholastic intelligence models which advocated scholastic intelligence tests. Behavioural model has the potential to be used across organisations in terms of its generalisability, but it overemphasises behaviours as the predominant predictor of success and competence. This approach ignores other potential factors such as knowledge, skills, abilities, attitudes, personal characteristics, and managerial functions (Mathis \& Jackson, 1997) that contribute and interact with behaviours to determine managerial success. This gives the behavioural model a narrow perspective of conceptualisation and modelling of managerial competencies. Also, it does not emphasise job-related functional skills, which are competency based and actually determine performance (Le Deist \& et al., 2005). It is precisely this weakness in the behavioural competency model that the functional model of competencies addresses.

\subsection{The Functional Model}

Functional competence models (Knasel \& Meed, 1994) emphasise the ability to demonstrate performance to the standard required in a particular job. Thus, it attests primarily to competence in a person's current post. This functional approach in which competence criteria 
and occupational standards of competence are grounded in the reality of work, has been the UK tradition and has influenced the development of similar frameworks in some countries in the Commonwealth and the European Union (Le Deist et al., 2005). The functional model is important in that it emphasises the competence required for one's performance. However, the model does not provide specific skills, knowledge abilities or capabilities required, for jobs. The job competence model addresses this shortfall by specifying components of competence and, also, attempting to show how the components interact with each other.

\subsection{The Job Competence Model}

In the job competence model (Mansfield \& Mathews, 1985), competence is seen as comprising three basic components: tasks; task management; and the role/job environment. Tasks consist of skills needed in a routine way to achieve specific outcomes. Task management involves the use of skills that may be needed when two or more tasks need to be performed together. Role/job environment is concerned with skills that are needed to cope with a particular work environment or a critical situation. The model attempts to show how these components interact with each other. For example, Mansfield and Mathews (1985) argued that the role/job environment component appear to be closely linked to personal effectiveness. However, the linkage is not well developed. Also, the model does not specify potential skills regarding task management and role/job environment competence (Cheetham \& Chivers, 1998).

Each of the models reviewed; behavioural, functional, and job competence models has specific emphasis which contributes to the development and understanding of the concept of competence. However, it appears that they are not holistic as they are limited in their domains hence their power to explain managerial competencies. The Holistic model (Cheetham \& Chivers, 1996, 1998), and the Multi-dimensional holistic model (Le Deist et al., 2005) address this shortfall by integrating the core concepts of the models reviewed earlier. Analysis of the two models indicates that they both appear to be similar in terms of the domain they cover, addressing the same issue with similar conceptualisations, but with different terminology and typology.

\subsection{Holistic Model}

The Holistic Model of managerial competency (Cheetham \& Chivers, 1996, 1998) is an improvement upon the behavioural, functional and the job competency models. It integrates the key dimensions emphasised by the behavioural, functional and job competency models, and introduces other skills in addition.Thus, comparatively, the holistic model appears more comprehensive than behavioural, functional and the job competency models discussed earlier The model has five key components: knowledge/cognitive component; functional competence; personal/behavioural competence; values/ethical competence; and meta-competence: Cheetham and Chivers (1996:24) define: the key components as follows: knowledge/cognitive competence as '...the possession of appropriate work related knowledge and the ability to put this to effective use'. Functional competence is defined as 'the ability to perform a range of work-based tasks effectively to produce specific outcomes'. A personal or behavioural competency is defined as 'the ability to adopt appropriate 
observable behaviours in work-related situations'. Values/ethical competence is defined as 'the possession of appropriate personal and professional values and the ability to sound judgements based upon these in work related situations'. Meta-competencies are concerned with communication, self-development, creativity, analytic and problem solving.

According to Cheetham and Chivers (1996, 1998) knowledge / cognitive competence, functional competence, personal/behavioural competence, and values/ethical competence are referred to as core competence and that they are separate aspects of competence but in reality interlinked and to some extent dependent on each other. However, the extent to which they are interlinked and dependent on each other is not clearly defined. Cheetham and Chivers emphasise that the meta-competencies either assist in developing other competencies or are capable of enhancing or mediating competencies in any or all of the component categories. Also, the same meta-competencies seem likely to be applicable to all or most professions because by their nature, they are fundamental and transferable between different situations and tasks. A major strength of this model is that it is more holistic and generic in the sense that it integrates behavioural and functional dimensions of competencies for performance. Also, it includes ethics and professional values required for effective performance.

\subsection{Multi-dimensional Holistic Model}

Extending the Holistic Model, Le Deist et al. (2005) argued for the usefulness of a holistic typology in understanding the combination of knowledge, skills and social competencies that are necessary for particular occupations and accordingly proposed a multi dimensional and holistic model of competencies. The model identifies four main components of competencies as: conceptual/cognitive, operational, social dimension/attitudes and meta competencies. A conceptual/cognitive component of competence comprises the underlying knowledge and understanding a person may have and apply to his/her work. The operational component is the functional aspect of competence, whereas the social component is about the appropriate social behaviours and work attitudes dimension of competence. Consistent with (Cheetham \& Chivers, 1996, 1998), the meta component is related to the facilitation and the acquisition of other substantive competencies. The model posits that cognitive, operational and social competencies are universal, that is generic which a person must have in order to be effective at work, but emphasises that all the four components are essential dimensions of competency.

The conceptual, operational and social competencies of the Multi-dimensional Holistic Model correspond to the cognitive, functional, and personal values or ethical dimensions of the holistic model (Cheetham \& Chivers, 1996, 1998)respectively. Both holistic and the multi-dimensional models consider these competencies as generic. The two models both emphasise meta competencies, concerned with the ability to develop other competencies, described as 'meta-qualities' - i.e., 'creativity, mental agility and balanced learning skill' and'meta-skills' i.e.' skills in acquiring other skills (Reynold\& Snell, 1988), Despite the holistic nature of the holistic and the multi-dimensional models, they emphasize more on functional, business/technical, cognitive and social skills, and give no attention to intrapersonal and leadership skills. These limitations are addressed inthe domain model of 
managerial competencies (Hogan \&Warrenfeltz, 2003) which appears to be more comprehensive, compared to the other models reviewed.

\subsection{The Domain Model of Managerial Competencies}

The domain model of managerial competencies (Hogan \& Warrenfeltz, 2003) posits that all lists of competencies can be organised into four main components comprising intrapersonal skill, interpersonal skill, business/technical skills, and leadership skills.

Business skills, also referred to as technical competencies (Reio\& Sutton, 2006) defined by the cognitive abilities and technical knowledge needed for the job, involve planning, monitoring budgets, forecasting costs and revenues, cutting costs, mapping strategies, evaluating performance, running meetings and organizing report. The model emphasizes that without reasonable interpersonal and leadership skills, good business skills would not really matter.

Intrapersonal skills are indicative of the 'core self-evaluations' construct, that is, 'the basic conclusions or bottom line evaluations that individuals hold about themselves' Some main traits comprising the core self-evaluation construct, an important component of intrapersonal skills are; core self-esteem, generalized self-efficacy, internal locus of control, self-control and emotional stability/emotional skills/emotional intelligence, integrity and resilience (Benthal et al., 2004;Boyatsiz, 2008,2009;Judge \& Bono, 2001; Kaiser \& Hogan, 2010). Core self evaluation traits are among the best dispositional predictors of job satisfaction(Judge \& Bono 2001). Also, intrapersonal skills form the foundation on which management careers are built in that successful managers receive high scores on measures of intra personal skills (Hogan\&Warrenfeltz, 2003).

Interpersonal skills are concerned with initiating, building and maintaining relationships with different people such as subordinates, peers and superiors. They are basic managerial skills and predictor of managerial performance and effectiveness (Hogan \& Hogan, 2001). The importance of interpersonal skills for managerial effectiveness is grounded in the Leader-Member-Exchange (LMX) theories of leadership (Gerstner \& Day, 1997; Graen\&Uhl-Bien, 1995; Schriesheim, Castro \&Cogliser, 1999). The LMX theories focus on the quality of exchanges and inter personal relationships between a manager and a subordinate as primary determinant of managerial effectiveness.

Effectiveness of managers depends on the extent to which they develop high quality interpersonal relationship with their subordinates. Those who develop good interpersonal relationship with their subordinates are considered as effective whereas those who are unable to develop high quality interpersonal relationships are considered ineffective. High quality interpersonal relationships with subordinates are important because they enhance their well being, job satisfaction, organisational commitment, organisational citizenship and performance (Gerstner \& Day, 1997; Schriesheim et al., 1999).McCall and Lombardo (1996) summarize the characteristics of failed managers, in essence managerial incompetence, in terms of: poor interpersonal skills, that is, being insensitive, arrogant, cold, aloof, overly, ambitious, inability to build a team and get work done at the team level. 
Leadership skills: Leadership is concerned with the ability to influence, motivate and direct individuals and groups to achieve organisational goals, mission or vision(Chemers, 2001). It is about interpersonal influence, persuasiveness, goal setting and team building, and is central to the success or failure of organisations (Furnham, 2002; Judge \& Bono, 2000). Leadership behaviour and effectiveness have important implications for employee well being, work attitudes and performance. Managers need to demonstrate leadership skills and qualities as there is the tendency for most organisations to be over-managed and under-led (Korterman, 2006). A manager with leadership abilities is described as first class manager or leader-manager, in contrast with a routine manager who is more concerned with technical competencies.

\subsubsection{Weakness in the Domain Model}

In the domain model of managerial competencies, Hogan and Warrenfetz (2003) posited that all managerial competencies can be categorised into four main skills: intra personal; interpersonal skill; leadership; and business skills. However, two important skills; career and mentoring, that are important for managerial performance and effectiveness were ignored in the model. This leaves a competency gap which this paper is addressing by including career success and mentoring skills as competencies for effective managerial performance. This is intended to make the model more holistic, increase its explanatory richness and power and describe the proposed extended domain model as 'holistic- domain model of managerial competencies'.

\subsubsection{Extended Domain Model: Integration of Career and Mentoring Skills}

\subsubsection{Career skills}

From an occupational and organisational perspective, Boerlijst (1998), defines career as a 'sequence of successive positions as ascertained by an observing agency (self and/or other) that a career occupant has held or acquired within a certain period of time on aspect variables that have a certain relevancy to a certain context like role, position, status or other externally verifiable markers'. The career concept is multidimensional and multifaceted, comprising many constructs and variablessuch as career development; (Boerlijst 1998; Millward, 2005); career success (Judge et al., 1995; Seibert\& Kramer, 2001; Tharenou, 1997); career advancement (Tharenou,1997); career progression (Thomas, et al., 2005; Tharenou,1997); career ladder; (Thomas et al., 2005; Millward,2005); executive career success, and managerial career success (Judge et al., 1995; Thomas et al., 2005) which are largely dependent on 'managerial career skills'. Therefore, career skill will be conceptualised in terms of career success. It is imperative then to examine the concept of career success, and link it to the concept of career skill.

Career success can be defined as the real or perceived achievements individuals have accumulated as a result of their work experiences (Judge, et al., 1995). Seibet and Kraimer (2001) defined it as the accumulated positive work and psychological outcomes resulting from one's work experiences. These definitions suggest that career success has a psychological dimension as a career is perceived, and then judged as successful and is 
therefore subjective. It can also denote a real or tangible work achievement or outcome and therefore be objective. Most researchers recognise these two facets and therefore conceptualise and operationally define career success into subjective and objective dimensions which are considered as different outcomes of an individual's career experiences (Judge et al., 1995; Judge, et al., 1999; Millward, 2005; Thomas et al., 2005).Subjective or intrinsic career success is defined as a person's feeling of accomplishment and satisfaction with his or her career, and it is most commonly conceptualised as consisting of two components: current job satisfaction and career satisfaction (Judge et al., 1995, 1999). In contrast, objective career success is defined as the extrinsic or observable work outcomes of a person that can be evaluated by others. Indicators of objective career success include pay and upward progression through a series of related jobs, the number of promotions in one's career, the attainment of high status, power and authority, and prestigious jobs. 'Objective' career may be either entirely dependent on progression within an organisation ('locals'), or dependent on a profession or occupation which may involve movement from one organisation to another ('cosmopolitan')(Millward, 2005).

Managerial career success is largely a function of two important career experiences: working hard (human capital)/contest mobility and receiving organisational support (sponsored mobility)(Thomas et al., 2005). Attracting and obtaining organisational support/sponsorship reflects a more political explanation for career success which involves some political skills. Political skill in organisational context is the ability to effectively influence others at work to act in ways that enhance one's personal and/or organisational objectives. It is about an employee's ability to recognise and leverage power differential at the work place to achieve personal and/or organisational objectives. Politically skilled employees are socially astute, capable of influencing others, interactive and good at social networking (Ferris et al.,2005, 2007; Treadway el., 2013). Thus, highlypolitically skilled employees are more likely than lowly politically skilled employees to influence power differentials at the workplace to attract organisational support/sponsorship for career development and success. In contrast, working hard represents a merit based explanation for career success because enhancing a person's competency through job-related knowledge, skills and abilities should be rewarded in the career contest.Internally generated facets, such as efficacy, resilience, self-insight, self-motivationare likely to facilitate personal success(Millward, 2005). Woking hard involves having higher need for career oriented goal achievement, work capability/efficacy, work commitment/perseverance, and investing extra/maximum effort/inputs for career progression and success (Asumeng, 2014).Intra-personal skills, that is core self-evaluations which develop in early life, predict a person's later career development and success. (Judge et al., 1999; Hogan \&Warrenfetz' (2003)

Drawing on Judge et al. (1995),Seibet and Cramer (2001), and Thomas et al. (2005) 'career skill' can be conceptualised in terms of managerial /executive career success, comprising two components: career satisfaction and job satisfaction. In the original domain model of managerial competencies, Hogan and Warrenfetz (2003) did not elaborate on 'career skills' in their model, although they argued that intra-personal skills laid the foundation for career success. On conceptual and empirical grounds, this paper argues that career success largely 
depends on career skills. But this was not considered in their model, leaving a competency gap which this paper is addressing by including career as a skill in the domain. The reason is that career skill is important because it is associated with managerial performance and effectiveness (Tharenou, 1997). Therefore, the concept of career skill is being proposed as an extension to fill the gap in the model to make it more holistic, increase its explanatory richness and power. The concept of career skill lends itself to the proposed extension of the domain model(Judge et al., 1999; Tharenou, 1997; Hogan \&Warrenfetz, 2003; Thomas et al., 2005). Thus, the domain model lends itself to inclusion of the concept of career skill to enhance the explanatory power of the model.

\subsubsection{Managerial Mentoring Skills}

Managerial mentoring is an interactive process where a manager serves as a role model, and provides support and direction for the younger employee regarding career plans and development. Specifically, managers help and oversee the lesser skilled or experienced employees acquire and develop job-specific skills and competencies and more importantly, career skills for professional development and for future job requirements Also, managers offer psychological and emotional support to mentees/protégé ( Bozeman \&Freeney, 2007; Carter, 2002; Chan \&Lathan, 2004; Reid, Allen, Reimeschnieder\& Armstrong, 2008;Noe et al., 2002).

Managers are situated to be mentors in organisational settings, that is, mentoring should be considered as part of managerial roles for the following reasons. Firstly, managers are being urged to promote people-oriented approach to management. They are not only responsible for business results, but also, for the development of their employees(Kaufman, 2006). Secondly, managers should not just develop their employees but, also, contemplate creating better people than themselves (Blacman-Sheppard, 2004). Thirdly, managers should consider mentoring as an organisational citizenship behaviour (OCB), and a personal, extra-organizational investment in the protégé. OCB is about individual behaviour that is discretionary, not directly or explicitly recognized by the formal reward system and promotes the effective functioning of the organisation. OCBs include helping an individual co-worker without expecting any reward. A key component of OCB is that omission of the behaviour is not punishable (Organ,1997).Fourthly, managers are responsible for creating and building learning organizations, that is, organisations that aim to create a climate of continuous learning and improvement at individual, group and organisational levels (Doyle, 2004).

Similar to other professional practices, mentoring encompasses knowledge and skills that must be learned. This is because mentoring is a broader concept as the mentor may employ skills, methods, models and approaches such as professional coaching and supervision, counselling, apprenticeship and role modelling, instructional, facilitating and guide in experiential learning (Baron et al., 2009; Garvey, 2004; Millward, 2005).Managers should have knowledge and experience of the mentee's area of work, knows organisational policies, routines and procedures, and can empower the mentee with the knowledge gained from their experience. Managers should be trained in task and support skills, leadership, supervisory, coaching, supportive, human relations communication and interpersonal skills to enhance 
their performance as mentors (Akportor, 2013;Schwille, 2008).In addition to the necessary mentoring knowledge skills and abilities, managers need to be motivated and have 'mentoring efficacy', that is the belief that they are capable, and effective in mentoring. Capability of managers to sense other employees' development needs and bolster their abilities has been described as social intelligence competence (Boyatzis,2008, 2009). Also, managers must feel 'psychologically safe' during the mentoring process without feeling threatened that their positions would be taken by the better people they produce in organisations. This, however, depends on their own career progression and success. That is, managerial career skills and progression are essential for the development of effective mentoring skills, and the likelihood to mentor others.

\subsubsection{Relevance of Mentoring and Career Skills to Managerial Effectiveness: Some Empirical} Evidence

Empirical evidence on the direct relationships between mentoring, career skills and managerial effectiveness appears scanty in the literature, analysis of the few related studies located suggests that the two managerial skills have positive impact on managerial and organisational effectiveness.

Although mentoring is intended to provide career development and psychological support functions to mentees, empirical evidence suggests positive relationships between mentoring, managerial career development, and managerial effectiveness (Raggins and Verbos, 2007; Nickols, 2010). That is, mentoring is beneficial for the mentee/protégé, the mentor/ manager and the organisation in general. Also, studies suggest that mentoring is relevant to managerial effectiveness because in mentoring managers develop their employees which enable them to be better equipped for performance improvement (Kaufman, 2006).Further, it is a way by which managers t create and build learning organisation which in turn benefits the individual employees, groups and the organisation (Doyle, 2004). Studies indicate that benefits for the manager are higher job satisfaction, increased motivation, enhanced career progression, success, revitalisation and satisfaction,. Also, it provides enhanced self-esteem and confidence, opportunity to develop new ideas for self-development and professional growth which enhance managerial job performance and effectiveness (Boziolonelos, 2004; Noe et al, 2002; Scandura, 1992).

Empirical evidence indicates that managerial career skills, progression and success are essential for the development of effective mentoring skills. Managers who mentor are high performers with high level of career success and satisfaction, compared to those who do not (Raggins\&Verbos, 2007).Also, studies indicate a link between managerial career progression/success, the development of mentoring skills and the tendency for a manager to mentor others. Managers who are successful in their careers are more likely to mentor others, compared to those who are not successful and satisfied with their careers(Allen, Eby, Poteet and Lima, 2004). Further, empirical evidence suggests that managerial career success is associated with enhanced managerial performance and effectiveness and organisational effectiveness. Benefits of mentoring for the organisation include reduced employee turnover, 


\section{Macrothink Institute $^{\mathrm{TM}}$}

increased organisational learning, more skilled and well-performing employees and increased organisational effectiveness (Doyle, 2004; Kaufman, 2006; Tharenou, 1999)..

In sum, in addition to their traditional managerial role and leadership responsibilities, managers must see mentoring as part of their responsibility. However, the tendency for a manger to mentor others largely depends on his/her career success. Extending Yukl's (1989) definition of a first-class manager as a manager with leadership abilities, in contrast to a routine manager, it is proposed that a first class manager is one with leadership and mentoring abilities. Thus, it is proposed that holistic managerial competencies comprise business/technical, leadership, interpersonal, intra-personal career and mentoring skills. This is precisely what the proposed Holistic-Domain Model of Managerial Competencies conceptualises.

\section{Proposed Holistic-Domain Model of Managerial Competencies}

Building on the Domain Model, the key elements in the proposed Holistic Domain Model of Managerial Competencies comprises six key domains: intrapersonal skills, interpersonal skills, leadership skills, technical/business skills, career skills and mentoring skills. In addition to the taxonomy competencies, protocols for measuring and assessing the sample competencies are provided. Summary of the model is presented in Table 1.

Table 1.Summary of Holistic Domain Model of Managerial Competencies

\begin{tabular}{|c|c|c|}
\hline Competency & $\begin{array}{l}\text { Sample Competencies } \\
\text { /Behavioural indicators }\end{array}$ & Assessment \\
\hline $\begin{array}{l}\text { Intra-personal } \\
\text { (Personal) }\end{array}$ & $\begin{array}{l}\text { Emotional stability, self } \\
\text { control, core self-esteem, } \\
\text { self-efficacy, self-awareness, } \\
\text { courage, willingness to take a } \\
\text { stand, career ambition, } \\
\text { hardworking, achievement } \\
\text {-orientation, perseverance, } \\
\text { resilience, integrity, } \\
\text { trustworthiness, patience, } \\
\text { creativity, adaptability. }\end{array}$ & $\begin{array}{l}\text { Self and others- subordinates, } \\
\text { colleagues, superiors. }\end{array}$ \\
\hline $\begin{array}{l}\text { Interpersonal } \\
\text { (Managerial, people domain) }\end{array}$ & $\begin{array}{l}\text { Building relationships, } \\
\text { empathy communication } \\
\text { skills, team building, } \\
\text { networking, feedback seeking, } \\
\text { sensitive to employees' } \\
\text { concerns, listens to and } \\
\text { understands others ideas and } \\
\text { interests, modest, } \\
\text { warm/friendly, sympathetic., } \\
\text { conflict management. }\end{array}$ & Subordinates, peers and superiors \\
\hline Leadership & Providing direction, support & Evaluated by others, especially \\
\hline
\end{tabular}




\begin{tabular}{|c|c|c|}
\hline (Managerial, people domain) & $\begin{array}{l}\text { and standards for } \\
\text { accomplishment, } \\
\text { communicating compelling } \\
\text { vision, motivating others, } \\
\text { inspiring, empowering, } \\
\text { resolving } \\
\text { conflicts/negotiating, hiring } \\
\text { and staffing strategically, } \\
\text { teamwork, managing } \\
\text { diversity, innovation, }\end{array}$ & subordinates. \\
\hline $\begin{array}{l}\text { Technical/Business/Management } \\
\text { (Managerial, task domain) }\end{array}$ & $\begin{array}{l}\text { Business acumen, quality } \\
\text { decision making, intellectual } \\
\text { capability, analytic thinking, } \\
\text { problem solving, } \\
\text { functional/technical skills, } \\
\text { planning, organizing ability, } \\
\text { priority setting, performance } \\
\text { enhancing, managing human } \\
\text { resources, managing } \\
\text { information and material } \\
\text { resources, innovation, } \\
\text { administration, developing } \\
\text { effective business strategy, } \\
\text { delegating. }\end{array}$ & $\begin{array}{l}\text { Self -evaluation, } \\
\text { Evaluated by others-superiors, } \\
\text { colleagues. } \\
\text {-360-degree } \\
\text { feedback/multi-system-multi-rater } \\
\text { assessment }\end{array}$ \\
\hline $\begin{array}{l}\text { Career } \\
\text { (Personal) }\end{array}$ & $\begin{array}{l}\text { Hardworking; goal } \\
\text { achievement orientation, work } \\
\text { capability/efficacy, work } \\
\text { commitment/perseverance, } \\
\text { investing extra/maximum } \\
\text { inputs. Organisational } \\
\text { support: political; socially } \\
\text { astute, influential, interactive, } \\
\text { socially networked. Objective: } \\
\text { pay, upward } \\
\text { progression/upward mobility, } \\
\text { number of promotions, } \\
\text { attainment of high } \\
\text { occupational status, power and } \\
\text { authority, prestigious jobs. } \\
\text { Subjective/intrinsic: current } \\
\text { job satisfaction, career } \\
\text { satisfaction }\end{array}$ & $\begin{array}{l}\text { Objective- Evaluated by others- } \\
\text { superiors, colleagues. Subjective- } \\
\text { self evaluation. }-360 \text { degrees } \\
\text { feedback. }\end{array}$ \\
\hline Mentoring & Personal- intrapersonal skills, & Personal- mentees/subordinates \\
\hline
\end{tabular}




\begin{tabular}{|c|c|c|}
\hline $\begin{array}{l}\text { (organisational citizenship } \\
\text { behaviour) }\end{array}$ & $\begin{array}{l}\text { interpersonal and } \\
\text { communication skills, } \\
\text { approachable, empathy, desire } \\
\text { to help others, supportive, } \\
\text { mentoring efficacy. } \\
\text { Professional- career } \\
\text { development skills, } \\
\text { teaching/instructional, } \\
\text { coaching, counselling, } \\
\text { facilitating, supervisory, } \\
\text { knowledge and experience of } \\
\text { the mentee's area of work, } \\
\text { knows organisational routines, } \\
\text { procedures and policies, } \\
\text { empowers the mentee, } \\
\text { leadership skills. }\end{array}$ & $\begin{array}{l}\text { Professional- mentees, superiors, } \\
\text { colleagues. } \\
\text {-360 degrees feedback. }\end{array}$ \\
\hline
\end{tabular}

The Holistic-Domain model expands the existing models of managerial competencies by incorporating key managerial competencies that have been ignored in the literature (career and mentoring skills). As indicated in Figure 1, these managerial competencies are intrapersonal, interpersonal, leadership, technical, career and mentoring skills and these contribute towards the success of the manager whether defined objectively or subjectively. 


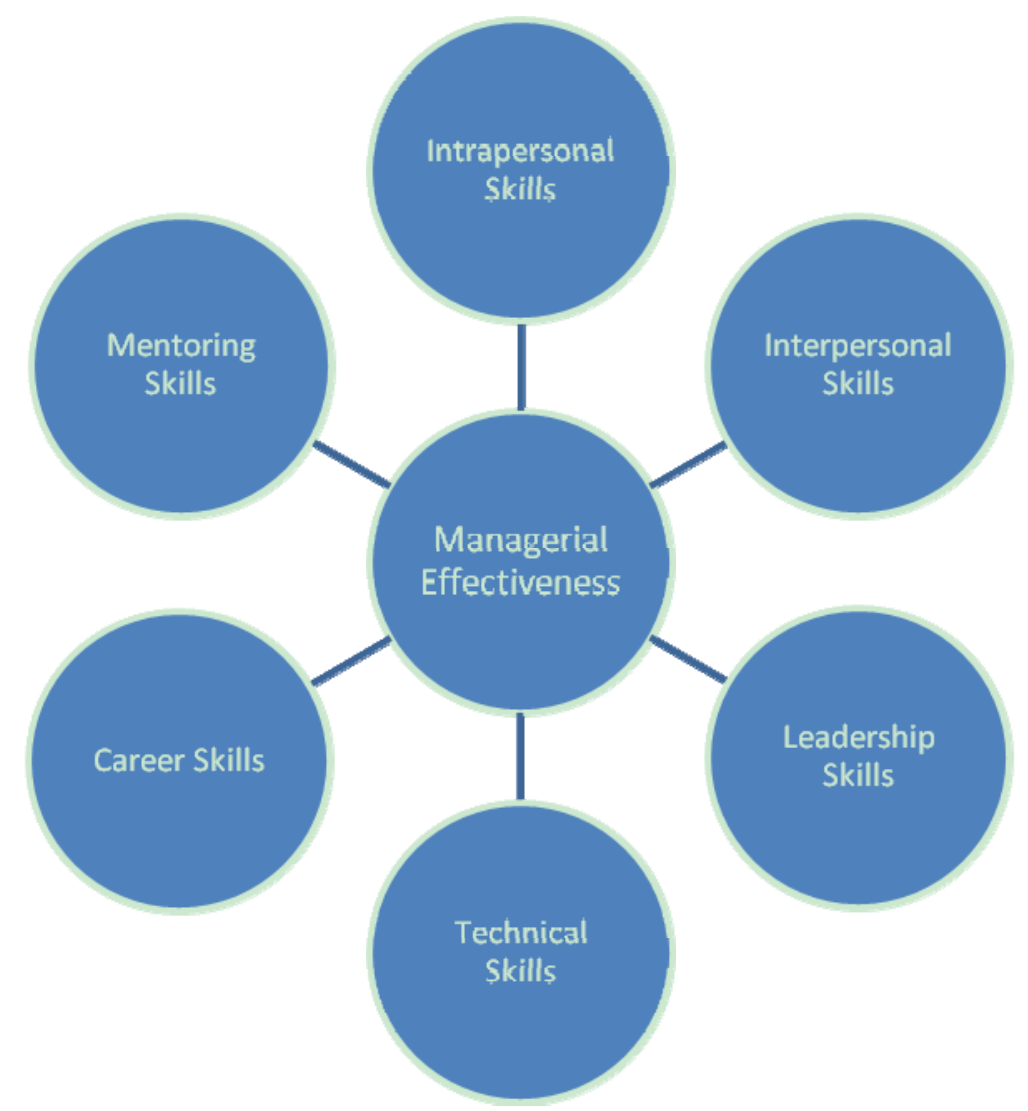

Figure 1. Holistic-Domain Model of Managerial Competencies

The intrapersonal competencies comprise personality characteristics such as emotional stability, self-control, self-esteem, self-efficacy, achievement-orientation, resilience, integrity and a host of others (see Table 1). These competencies can be assessed with standard psychological inventories whiles self and other reports can be potential sources of information about the intrapersonal competencies. Similarly, the interpersonal competencies comprise the communication skills, team-building, feedback-seeking, and conflict management skills. Details of the other competencies are presented in Table 1.

6.1 Theoretical, Practical and Research implications and Limitations of Holistic-Domain Model

In other to provide preliminary support for the model, it is assessed in terms of providing an explanatory framework, practice, and research. Conceptually, this generic model of managerial competencies is an expanded one which appears more comprehensive than those located in the literature and reviewed. This is because in addition to business, leadership, interpersonal and intra personal skills, it incorporates two competencies (career and mentoring skills) that have been ignored in the literature on managerial competencies. Thus the model offers a greater explanatory capacity in examining the relationship between managerial competencies and managerial effectiveness. This is because the inclusion of career and mentoring skills is likely to increase the size of the relationship between managerial competencies and managerial effectiveness. 
In terms of practice, this model provides guidelines or framework for practitioners in managerial assessment for selection, development and performance management. For example, during the assessment for managerial selection, the six competencies can be assessed as the domains or correlates of managerial performance. Also, these competencies can be considered as the basis of management development programmes as competencies needed in order to be effective can be developed in adults (Boyatzis, 2009).Similarly, the six competencies may be considered as the important dimensions of managerial performance and assessed appropriately.

The Holistic-Domain model also contributes to research insofar as the competencies outlined in the model (Refer to Figure 1 and Table 1) can be measured in studies and be related to the different indicators of managerial effectiveness. Further, studies can be conducted to assess the incremental validity of additional competencies incorporated into the model. This can be tested empirically and statistically via multiple regression analysis and structural equation modelling. However, this model is preliminary and conceptual, and will require empirical studies to verify its contributions to prediction of managerial effectiveness. Despite this limitation, the model provides a useful framework for theory, research and practice which needs to be given considerable attention.

\section{Conclusion}

In sum, the Holistic-Domain model, though a preliminary model, fills an important gap in the managerial competencies literature by drawing attention to the lack of attention to career and mentoring skills as potentially relevant to managerial performance and effectiveness. It provides a conceptual framework for a comprehensive and holistic generic managerial competency model building which has implications for theory, practice and empirical research.

\section{References}

Akportor, J. (2013) Managers as mentors in formal organisations. In A.A. Olowu (ed.) Mentoring: A key issue in human resource management, pp. 367-377. Ile-Ife, Nigeria. Ife Centre for Psychological Studies.

Amage, N., Rinthasong, I., \&Songsong, A. (2014).Factors influencing behavioural competency for competitiveness and success of Thai-Malaysia Border Trade Entrepreneurs to support ASEAN Economic Community (AEC).Journal of Management Research, 6(2), 221-231. http://dx.doi.org/10.5296/jmr.v6i2.5437

Asumeng M.A. (2014). What it means to work hard for career progression: a qualitative study among managers in Ghana. Journal of Management, 2(2/3). (forthcoming)

Baron, A. R., Branscombe, R. N., \& Byrne, D. (2009). Social Psychology (12 ${ }^{\text {th }}$ Ed.). Pearson Educ. Inc

Blackman, Sheppard, G. (2004). Executive coaching, Industrial and Commercial Training, 36(1), 5-8. http://dx.doi.org/10.1108/00197850410516049 
Boerlijst, J.G. (1998). Career development and career guidance.In P.J.D. Drenth, H

Boyatzis, R. E. (1982). The competent Manager: A model for effective performance. New York. Wiley.

Boyatzis, R. E. (2008). Competencies in the twenty-first century.Journal of Management Development, 27(1), 5-12. http://dx.doi.org/10.1108/02621710810840730

Boyatzis, R. E. (2009). Competencies as a behavioural approach to emotional intelligence.Journal of Management Development, 28(9), 749-770. http://dx.doi.org/10.1108/02621710910987647

Bozeman, B., \& Feeney, M.K. (2007). Toward a Useful Theory of Mentoring: A Conceptual Analysis and Critique. Administration and Society, 6, 719-739. http://dx.doi.org/10.1177/0095399707304119

Carter, A. (2002). Executive coaching: Inspiring performance at work, IES Report 379: Brighton, Institute for Employment Studies.

Chan, C., \& Latham, G.P. (2004). The relative effectiveness of external, peer and self coaches. Applied Psychology, 260-278. http://dx.doi.org/10.1111/j.1464-0597.2004.00171.x

Cheetham, G.,\&Chivers, G. (1996). Towards a holistic model of professional competence. Journal of European Industrial Training, 20(5), 20-30. http://dx.doi.org/10.1108/03090599610119692

Cheetham, G.,\&Chivers, G. (1998).The reflective (and competent) practitioner: a model of professional competence which seeks to harmonise the reflective practitioner and competence based approaches. Journal of European Industrial Training, 22(7), 267-276. http://dx.doi.org/10.1108/03090599810230678

Chemers, M.M. (2001). Leadership effectiveness: An integrative review. In M.A. Hogg \& R.S. Tindale (Eds.), Blackwell handbook of social psychology: Group processes (pp.376-399). Oxford, UK: Blackwell.

Chen, G., \&Bliese, P.D. (2002). The role of different levels of leadership in predicting self-and collective efficacy: evidence for discontinuity. Journal of Applied Psychologym, 87(3), 549-556. http://dx.doi.org/10.1037/0021-9010.87.3.549

Church, A.H., \&Rotola, C.T. (2013). How are the top managers assessing their high potentials and executives? Consulting Psychology: Practice and Research, 65(3), 199-223. http://dx.doi.org/10.1037/a0034381

Doyle, C. E. (2004). Work and Organisational Psychology: An introduction with attitude. Psychology Press. New York.

Employment Department \& NCVQ (1991). Guide to National Vocational Qualifications, Sheffield, ED. 
Ferris, G.R., Treadway, D.C., Kolodinsky, R.W., Hochwarter, W.A., Kackmar, C.J., Douglas, C., \&Frink, D. (2005). Development and validation of the political skill inventory. Journal of Management, 31, 126-152. http://dx.doi.org/10.1177/0149206304271386

Ferris, G.R., Treadway, D.C., Perrere, P.L., Brouer, R.L., Douglas, C., \& Lux, S. (2007). Political skill in organisations. Journal of Management, 33, 290-230. http://dx.doi.org/10.1177/0149206307300813

Furnham, A. (2002). The Psychology of behaviour at work: The individual in the organisation. Psychology Press. Hove.

Gerstner, C.R., \& Day,.V. (1997). Meta-analytic review of Leader- Member-Exchange Theory: Correlates and construct issues. Journal of Applied Psychology, 82, 827-844. http://dx.doi.org/10.1037/0021-9010.82.6.827

Hogan, R., \&Warrenfeltz, R. (2003). Educating the modern manager. Academy of $\begin{array}{llll}\text { Management Learning } \quad \text { and } & \text { 2(1), }\end{array}$ http://dx.doi.org/10.5465/AMLE.2003.9324043

Hogan, R.,\& Hogan, J. (2001). Assessing leadership: A view from the darkside: International Journal of Selection and Assessment, 9(2), 40-51. http://dx.doi.org/10.1111/1468-2389.00162

Judge, T. A., Bono, J. E., Ilies, R., \& Gerhardt, M. W. (2002). Personality and Leadership: A Qualitative and Quantitative Review. Journal of Applied Psychology, 87(4), 765-780. http://dx.doi.org/10.1037/0021-9010.87.4.765

Judge, T. A., Higgins, C. A., Thoresen, C. J. \&Barrick,, M.R. (1999). The big five personality traits, general mental ability, and career success across life span:. Personnel Psychology, 52, 621- 652. http://dx.doi.org/10.1111/j.1744-6570.1999.tb00174.x

Judge, T. A.., \& Bono, J. E., (2001). Relationship of core self-evaluations traits - self esteem, generalized self-efficacy, locus of control, and emotional Stability - with job satisfaction and job performance: A Meta- Analysis.Journal of Applied Psychology, 86(1), 80-92. http://dx.doi.org/10.1037/0021-9010.86.1.80

Judge, T. A.., Daniel, M.C., \& Boudreau, J.W. \&Bretz, (1995). An empirical investigation of predictors of executive career success.Personnel Psychology, 48, 485-519. http://dx.doi.org/10.1111/j.1744-6570.1995.tb01767.x

Judge, T.A., \& Bono, J. E., (2000). Five-factor model of personality and transformational leadership. Journal of Applied Psychology, 85(5) 751-765. http://dx.doi.org/10.1037/0021-9010.85.5.751

Kaiser, R.B.,\& Hogan, R. (2010). How to (and how not to) assess the integrity of managers.Consulting Psychology: Research \& Practice, 62(4), 216-234. http://dx.doi.org/10.1037/a0022265

Knasel, E.,\&Meed, J. (1994). Becoming competent: Effective Learning for Occupational Competence. Sheffield: Employment Department. 
Kotterman, J. (2006). Leadership versus Management: What is the difference? The Journal for Quality and Participation, Summer, 13-17

Lado, A., \&Wilson, M. (1994). Human resource systems and sustained competitive advantage: A competency based perspective. Academy of Management Review, 19(4), 708-709.

Le Deist, F.D., Delamare, F., \&Winterton, J. (2005). What is competence? Human Resource Development International, 8(1), 27-46. http://dx.doi.org/10.1080/1367886042000338227

Mansfield, R.,\& Mathews, D. (1985). Job Competence: A Description for Use in Vocational Education and Training. Further EducationCollege. Blagdon.

Mathis, R.L.,\& Jackson, J.H. (1997). Human resource management ( $8^{\text {th }}$ edn.). Minneapolis/ St Paul: West.

McCall, M.W., \& Lombardo, M.M. (1983). Off the track: Why and how successful executives get derailed. Greensboro, NC. Centre for Creative Leadership. http://dx.doi.org/10.1037/h0034092

McClelland, D. (1973). Testing for competence rather than for 'intelligence'. American Psychologist. http://dx.doi.org/10.1111/1467-9280.00065

McClelland, D. (1998. Identifying competencies with behavioural-event interviews. Psychological Science, 9(5), 331-339.

Millward, L. (2005). Understanding Occupational \& Organisational Psychology. Sage Publications, London.

Naquin, S.S., \& Holton, E. F., III. (2006). Leadership and managerial competency models: A simplified process and resulting model. Advances in Developing Human Resources, 8(2). 144-165. http://dx.doi.org/10.1177/1523422305286152

Noe, R. A., Greenberger, D. B., \& Wang, S. (2002). Mentoring: What we know and where we might go. In G.R. Ferris \& J.J. Martocchio (Eds.), Research in personnel and human resources management (pp. 122 - 174). New York: JAI.

Organ, D.W. (1997). The motivational base of organisational citizenship behaviour. It's construct clean up time. Research in Organisational Behaviour, 12, 43-72.

Reid, M.F., Allen, M.W., Riemenschneider, C. K., \& Armstrong, D. J. (2008). The Role of Mentoring and Supervisor Support for State IT Employees' Affective Organisational Commitment. Review of Public Personnel Administration, 28(1), 60-78. http://dx.doi.org/10.1177/0734371X07311703

Reynolds, M.,\& Snell, R. (1988). Contribution to Development of Management Competence. Manpower Services Commission, Sheffield. 
Schriesheim, C. A., Castro, S.L., \&Cogliser, C. C. (1999). Leader-member exchange research: A comprehensive review of theory, measurement, and data-analytic practices. Leadership Quarterly, 10, 63-113. http://dx.doi.org/10.1016/S1048-9843(99)80009-5

Schwille, S. A. (2008). The Professional Practice of Mentoring. American Journal of Education, 115, 139 - 167. http://dx.doi.org/10.1086/590678

Seibert, S.E.,\& Kramer, M. L. (2001). The five- factor model of personality and career success. Journal of Vocational Behaviour, 58, 1-21. http://dx.doi.org/10.1006/jvbe.2000.1757

Spencer, L.M. \& Spencer, S.M. (1993). Competence at work: Models for superior performance. New York: Wiley.

Tharenou, P. (1997). Managerial career advancement. In C.L. Cooper \&I. T. Robertson (Eds.), International Review of Industrial and Organizational Psychology, 12, 49-91. Wiley.

Tharenou, P. (2004). The relationship of training motivation to participation in training and development. Journal of Occupational and Organisational Psychology, 74, 599-621. http://dx.doi.org/10.1348/096317901167541

Thierry,\& C.J. de Wolff (Eds.), Personnel Psychology.Vol. 3.Handbook of work and organisational Psychology.(2 ${ }^{\text {nd }}$ edn, pp. 273-296).Hove: Psychology Press.

Thomas, W.H. N.G., Eby, L.T., Sorensen, K. L., \&Fieldman, D.C. (2005). Predictors of subjective and objective career success: A meta-analysis. Personnel Psychology, 58, 367-408. http://dx.doi.org/10.1111/j.1744-6570.2005.00515.x

Treadway, D.C., Shaughnessy, B.A., Breland, J.W.Renmin, J.Y. \&Revees, M (2013).Political skill and the job performance of bullies.Journal of Managerial Psychology, 28(3), 273-289. http://dx.doi.org/10.1108/02683941311321169

White, R. (1959). Motivation considered: the concept of competence. Psychological Review, 66, 279-333. http://dx.doi.org/10.1037/h0040934

Yukl, G. (1989). Managerial Leadership: A Review of Theory and Research. Journal of Management, 15, 254-289. http://dx.doi.org/10.1177/014920638901500207

\section{About the author}

Maxwell Asumeng received his PhD in Occupational Psychology from the University of Surrey, and is currently a Senior Lecturer in Industrial Psychology and Organisational Behaviour in the University of Ghana. His research has been published in journals such as Journal of Managerial Psychology, International Journal of Management, European Journal of Business and Social Science, European Journal of Business and Management, International Journal of Human Resource Studies and South African Journal of Industrial Psychology. He has particular research interests in the development of managerial competencies, psychology of feedback and performance management in managerial and business contexts. 
